\title{
Algal subsidies enhance invertebrate prey for threatened shorebirds: A novel conservation tool on ocean beaches?
}

Thomas A. Sc

Briony M. Hutton ${ }^{\mathrm{b}, c}$

bhutton@deakin.edu.au

Ben L. Gilby

bgilby@usc.edu.au

Nicholaus Porch ${ }^{\mathrm{b}, \mathrm{c}}$

nporch@deakin.edu.au

Grainne S.

Grainne.Maguire@birdlife.org.au

Brooke Masl

brooke.maslo@rutgers.edu

Rod M. Connolly

r.connolly@griffith.edu.au

Andrew D.

aolds@usc.edu.au

Michael A.

mike.weston@deakin.edu.au

aschool of Science and Engineering, The University of the Sunshine Coast, Q-4558, Maroochydore, Australia

beakin University, Geelong, Australia

${ }^{\mathbf{c}}$ Centre for Integrative Ecology, School of Life and Environmental Sciences, Faculty of Science, Engineering and the Built Environment, Burwood, VIC, 3125, Australia



${ }^{\mathbf{e}}$ Department of Ecology, Evolution and Natural Resources, Rutgers, The State University of New Jersey, United States

fAustralian Rivers Institute - Coast \& Estuaries, School of Environment, Gold Coast Campus, Griffith University, Queensland, 4222, Australia

${ }^{*}$ Corresponding author.

\section{Abstract}

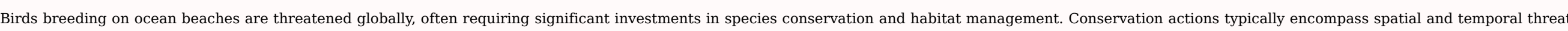
reductions and protection of eggs and broods. Still, populations decline or recover only slowly, calling for fresh approaches in beach-bird conservation.

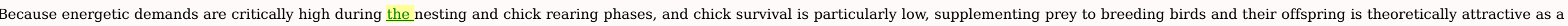


means to complement more traditional conservation measures.

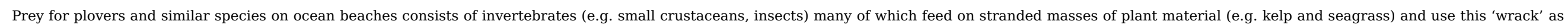
habitat. We added wrack to the upper beach where plovers nest and their chicks forage to test whether algal subsidies promote the abundance and diversity of their invertebrate prey.

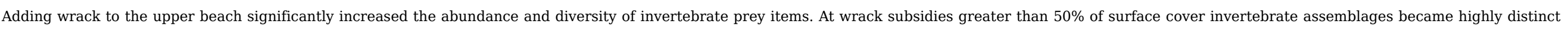
compared with those that received smaller additions of wrack. Substantial (2-4 fold) increases in the abundance amphipods and isopods that are principal prey items for plovers drove these shifts.

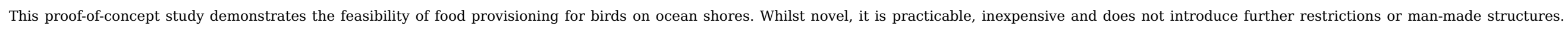
Thus, it can meaningfully add to the broader arsenal of conservation tools for threatened species that are wholly reliant on sandy beaches as breeding and foraging habitats.

Keywords: Wildlife conservation; Sandy beaches; Kelp; Plovers; Endangered species management

\section{Introduction}

Even as poor birds, deceived with painted grapes,

Do surfeit by the eye and pine the maw,

Even so she languisheth in her mishaps,

As those poor birds that helpless berries saw.

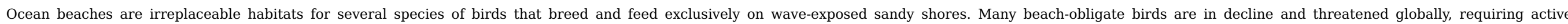

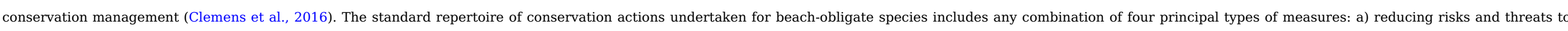

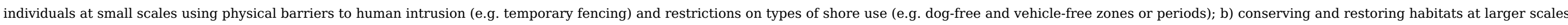

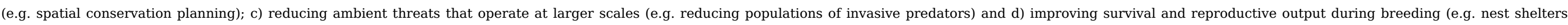

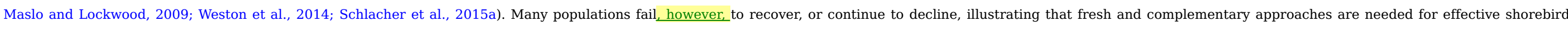
conservation.

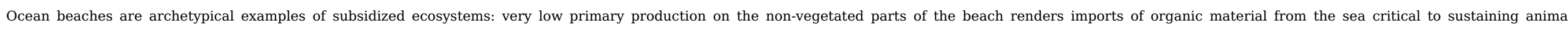

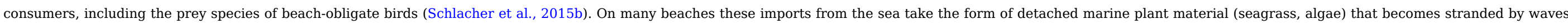



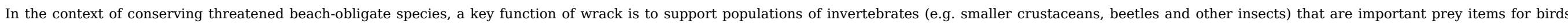

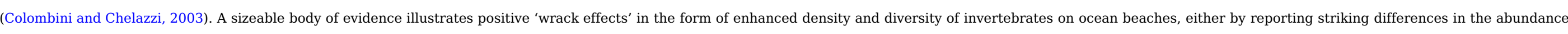

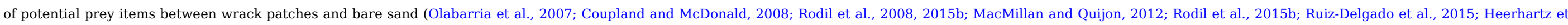



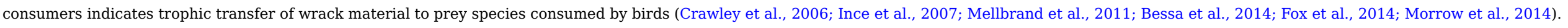

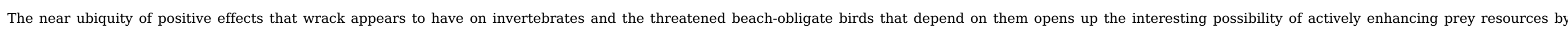

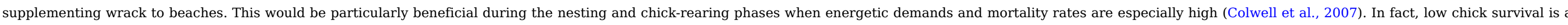

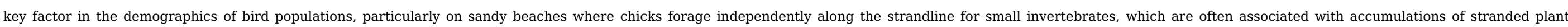

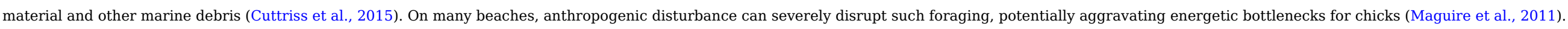

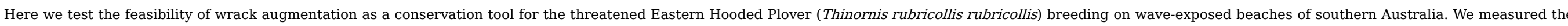




\section{Material and methods}

\subsection{The model species}

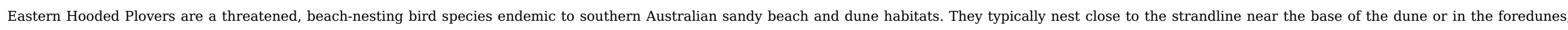

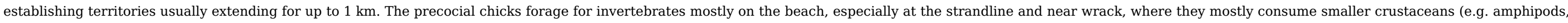

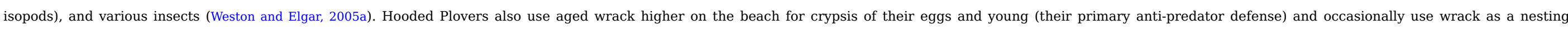
material; they may also consume some wrack, but such consumption may be incidental (Maguire et al., 2012).

\subsection{Study site and experimental design}

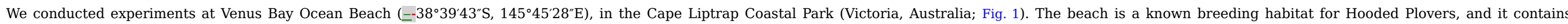

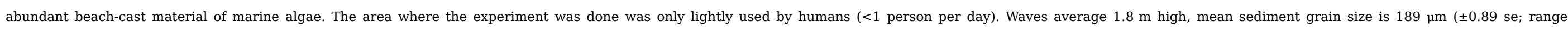
$183-211 \mu \mathrm{m})$, and the beach slopes at $11.30^{\circ}\left(2.31 \mathrm{se}\right.$; range: $\left.5.00-25.50^{\circ}\right)$

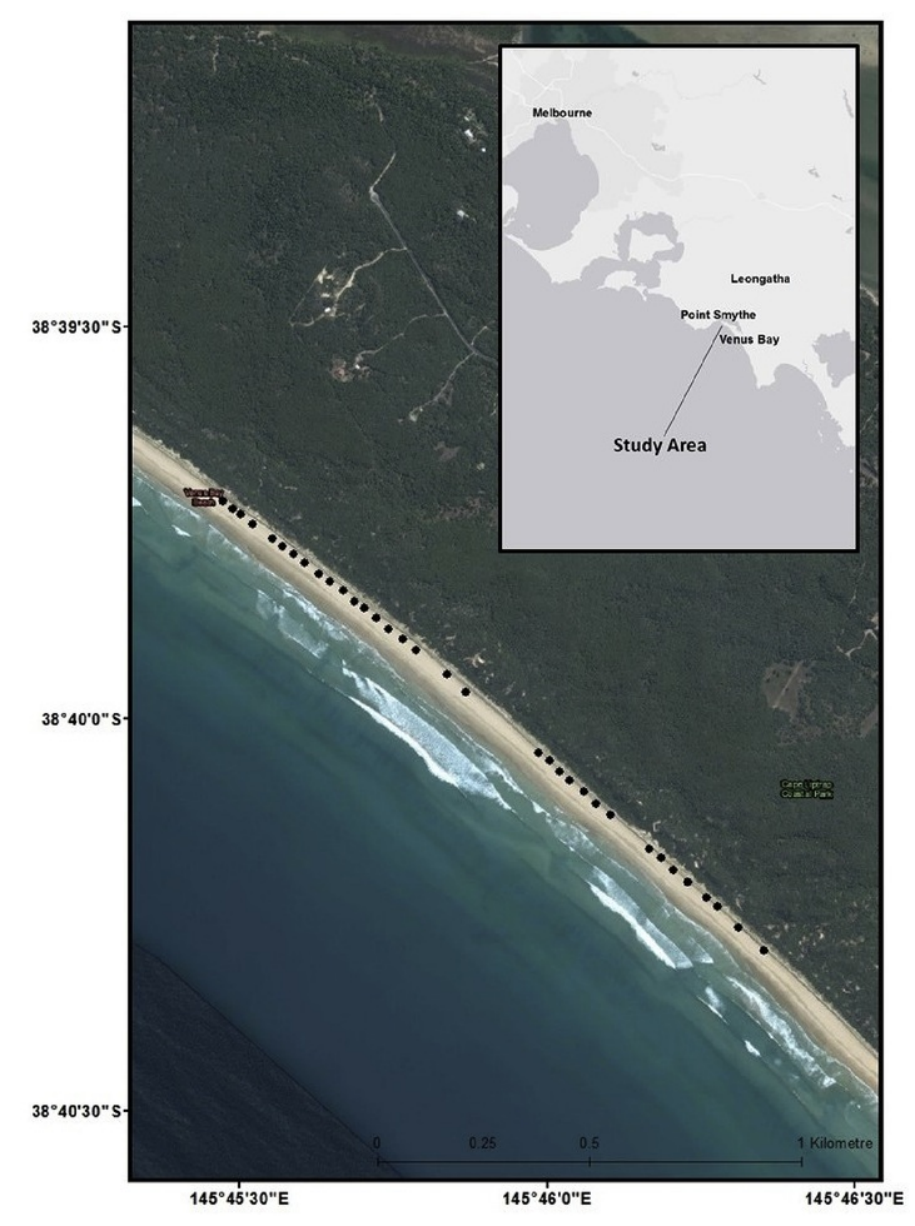




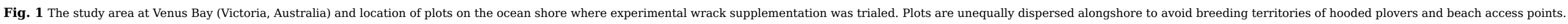
alt-text: Fig. 1

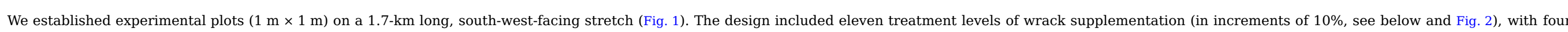

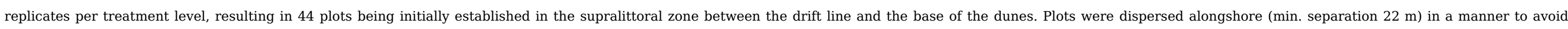
active breeding territories of plovers and beach access paths used by humans.
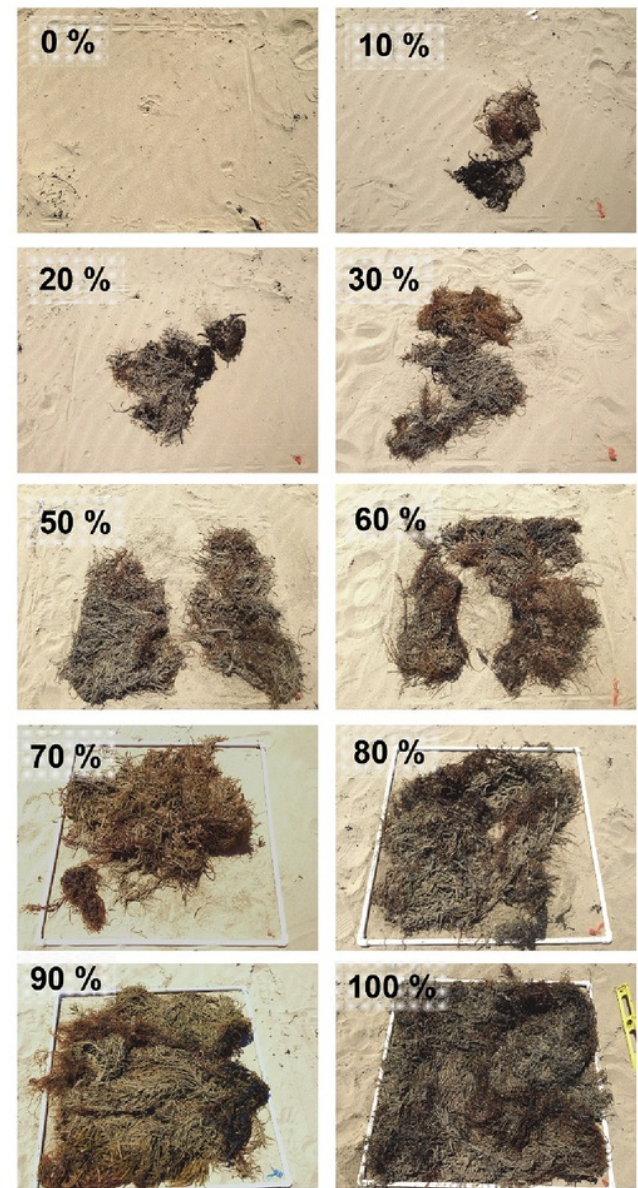

Fig. 2 Examples of experimental treatment levels consisting of increasing surface cover of macrophyte wrack added to $1 \times 1 \mathrm{~m}$ plots $(\mathrm{n}=44)$ on the upper beach.

\section{alt-text: Fig. 2}

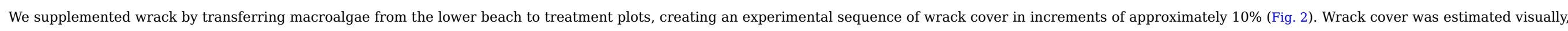



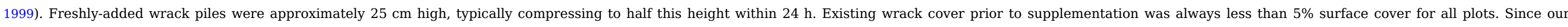

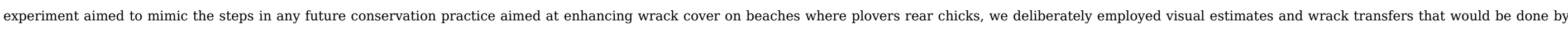

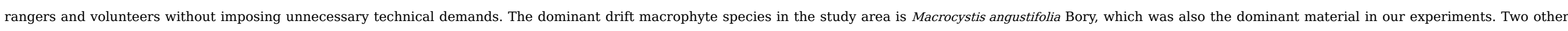




\subsection{Indexing fauna and environmental conditions}

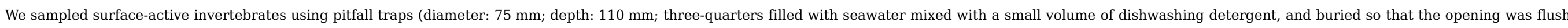

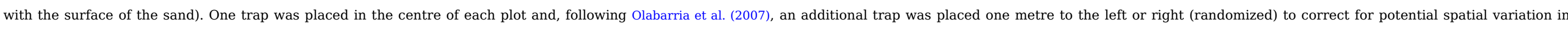

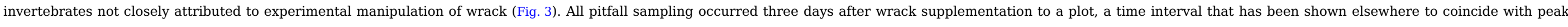

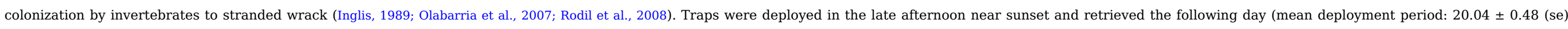
hours. Trapping period is included as a co-variate in all statistical analyses.

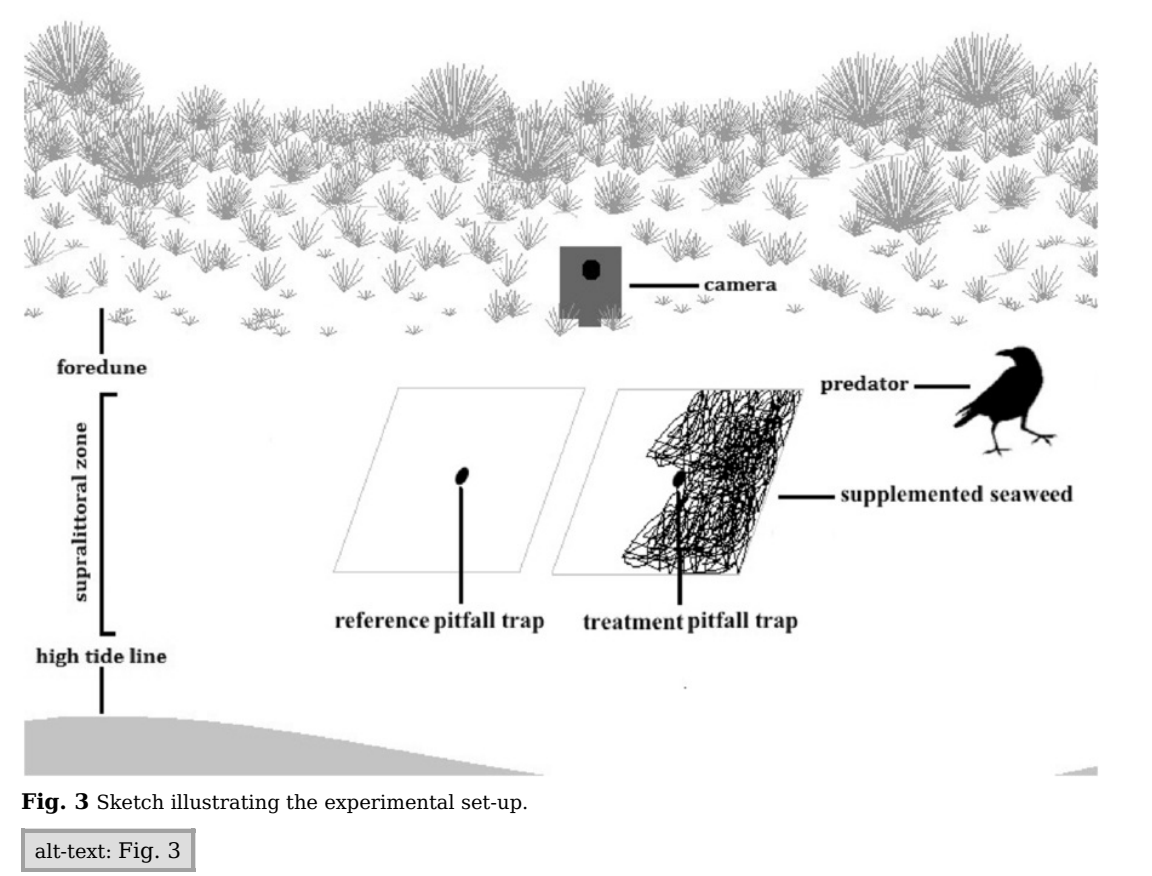

\section{alt-text: Fig. 3}

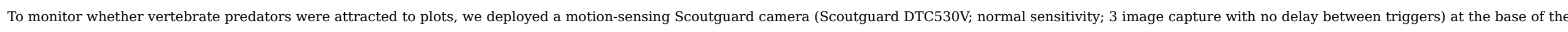





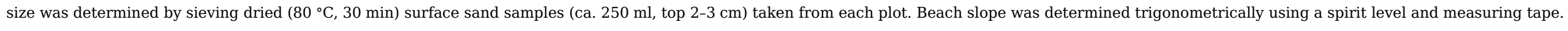

\subsection{Numerical analyses}

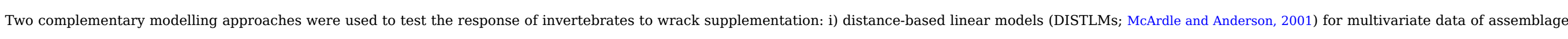
structure, and ii) generalised additive models (GAMs; Hastie and Tibshirani, 1990; Guisan et al., 2002) for composite measures of total abundance and species richness.

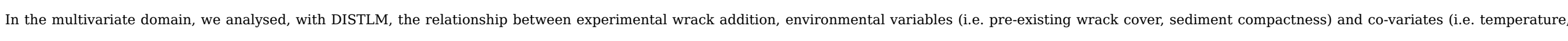

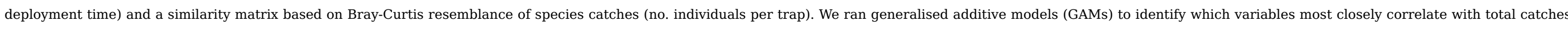




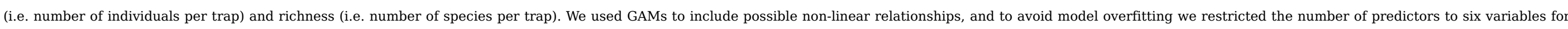



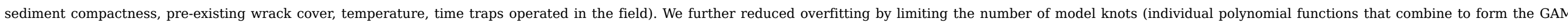

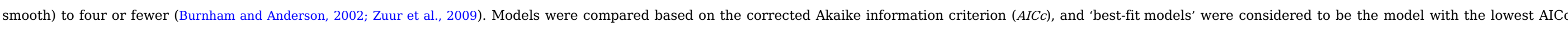

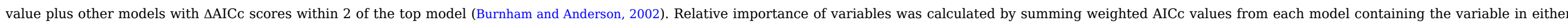
the DISTLMs or GAMS.

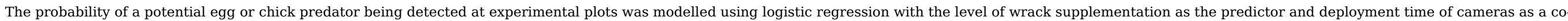
variate (to account for possible difference in detection due to shorter or longer camera operation).

\section{Results}

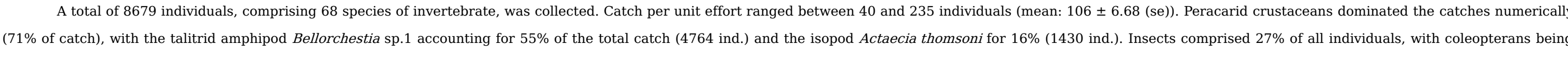

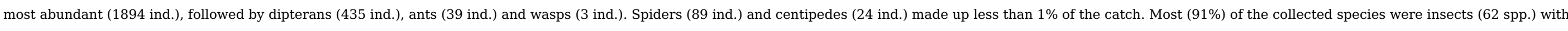

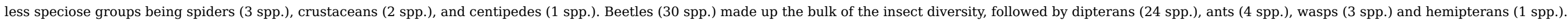

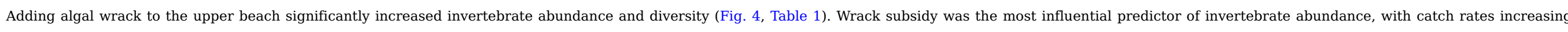

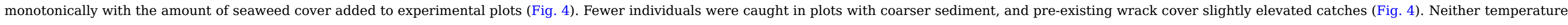

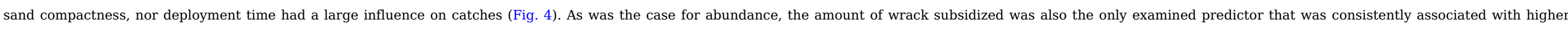

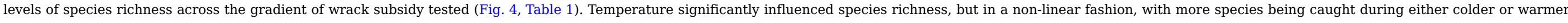
nights; no other examined environmental variable was significantly correlated with species richness (Fig. 4). 


\section{Abundance}
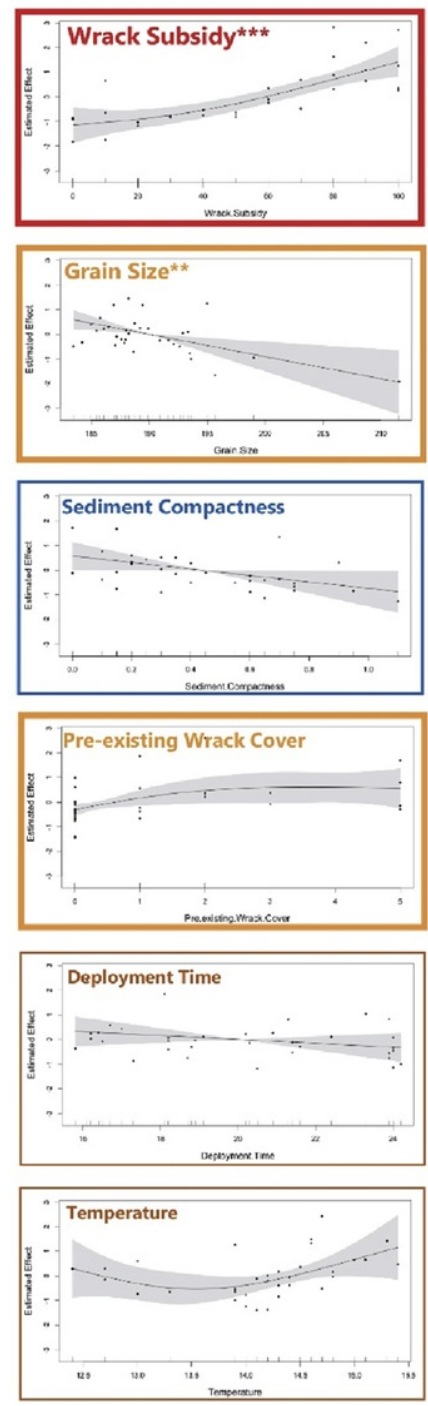

\section{Importance Value}

$\square^{<0.2 \quad \square^{0.2-0.4}}$

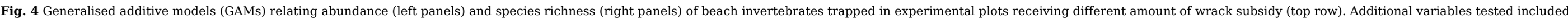

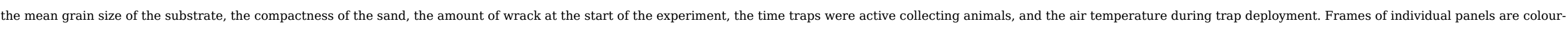
coded to reflect importance values of individual predictors in the overall GAMS model (cf. Table 1). (For interpretation of the references to colour in this figure legend, the reader is referred to the web version of this article.) alt-text: Fig. 4

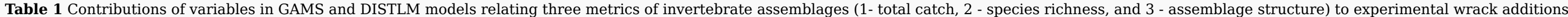






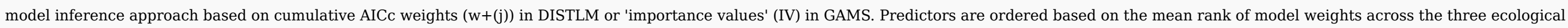
response variables.

\begin{tabular}{|c|c|c|c|c|c|c|}
\hline \multirow[t]{3}{*}{ Variable } & \multicolumn{2}{|r|}{ GAMS } & & & \multicolumn{2}{|c|}{ DISTLM } \\
\hline & \multicolumn{2}{|c|}{1 - Catch (Abundance) } & \multicolumn{2}{|c|}{2 - Species Richness } & \multicolumn{2}{|c|}{3 - Assemblage Structure } \\
\hline & IV & (P) & IV & (P) & $w+(j)$ & \\
\hline Wrack Subsidy (\%) & 1.00 & $(0.001)$ & 0.68 & $(0.060)$ & 0.98 & $\#$ \\
\hline Temperature $\left({ }^{\circ} \mathrm{C}\right)$ & 0.23 & $(0.180)$ & 0.71 & $(0.140)$ & 0.68 & \# \\
\hline Deployment Time (hrs) & 0.39 & $(0.270)$ & 0.28 & $(0.870)$ & 0.49 & \\
\hline Grain Size $(\mu \mathrm{m})$ & 0.71 & $(0.005)$ & 0.28 & $(0.300)$ & 0.32 & \\
\hline Pre-existing Wrack Cover (\%) & 0.64 & $(0.070)$ & 0.23 & $(0.630)$ & 0.45 & \# \\
\hline Sand Compactness $(\mathrm{cm})$ & 0.54 & $(0.050)$ & 0.19 & $(0.800)$ & 0.39 & \\
\hline
\end{tabular}

\# included in best overall model based on lowest AICc value.

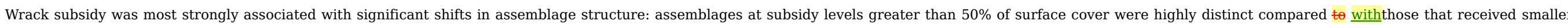

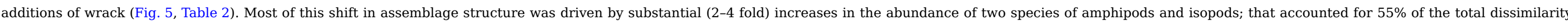

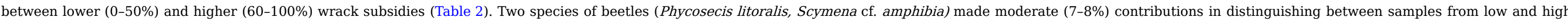

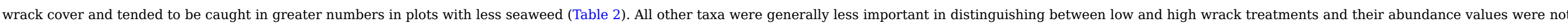
consistently greater or lower in either treatment (Table 2).

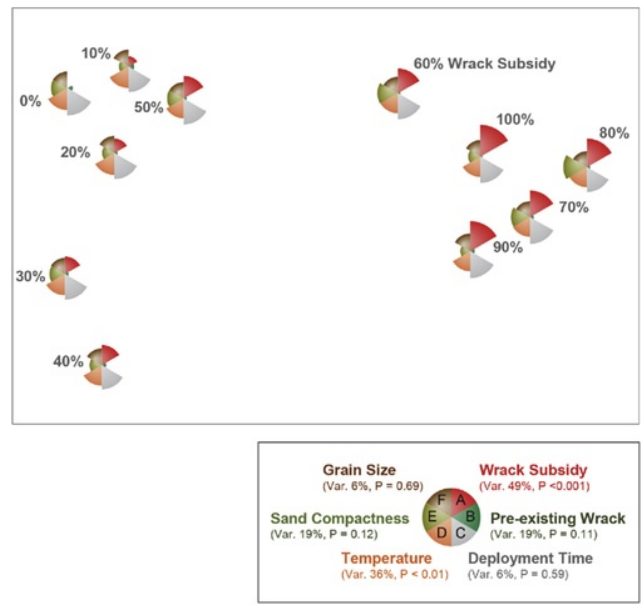

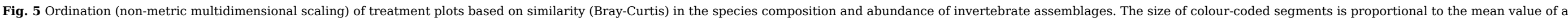

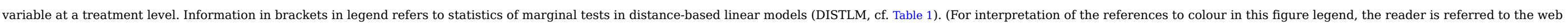
version of this article.) 



comparisons

\begin{tabular}{|c|c|c|c|c|c|c|}
\hline \multirow[t]{2}{*}{ Taxon } & ‘Low’ Wrack Subsidy (0-50\% Cover) & ‘High' Wrack Subsidy (0-50\% Cover) & \multirow[t]{2}{*}{ Av.Diss } & \multirow[t]{2}{*}{ Diss/SD } & \multirow[t]{2}{*}{ Contrib. \% } & \multirow[t]{2}{*}{ Cum. \% } \\
\hline & Mean Abundance (ind. trap-1) & Mean Abundance (ind. trap-1) & & & & \\
\hline Crustacea (Talitridae), Bellorchestia sp.1 & 35.15 & 78.92 & 19.83 & 3.27 & 42.33 & 42.33 \\
\hline Crustacea (Actaeciidae), Actaecia thomsoni & 4.28 & 16.42 & 6.01 & 1.23 & 12.84 & 55.17 \\
\hline Coleoptera (Tenebrionidae), Scymena cf. amphibia & 9.62 & 1.26 & 3.89 & 1.66 & 8.31 & 63.48 \\
\hline Coleoptera (Phycosecidae), Phycosecis litoralis & 13.52 & 11.61 & 3.17 & 1.37 & 6.77 & 70.24 \\
\hline Coleoptera (Staphylinidae), Sartallus signatus & 0.25 & 5.14 & 2.14 & 0.67 & 4.57 & 74.81 \\
\hline Coleoptera (Staphylinidae), Cafius sp.1 & 3.3 & 0.18 & 1.43 & 2.69 & 3.06 & 77.87 \\
\hline Coleoptera (Phycosecidae), Phycosecis litoralis (larvae) & 0.33 & 3.38 & 1.39 & 1.04 & 2.97 & 80.84 \\
\hline Coleoptera (Staphylinidae), Bledius sp.1 & 2.13 & 1.68 & 1.02 & 1.47 & 2.17 & 83.01 \\
\hline Coleoptera - Larvae OTU-L2 & 2.07 & 3.24 & 0.95 & 1.14 & 2.03 & 85.04 \\
\hline Diptera (Dolicophodidae) & 2.47 & 1.76 & 0.84 & 1.3 & 1.8 & 86.84 \\
\hline Diptera (Canacidae) OTU-D2 & 0.4 & 1.51 & 0.55 & 0.97 & 1.18 & 88.02 \\
\hline Aranea (Lycosidae), OUT-A1 & 1.53 & 0.93 & 0.5 & 1.28 & 1.07 & 89.09 \\
\hline Dipteran - OTU-D5 & 1.07 & 1.17 & 0.43 & 1.45 & 0.92 & 90.02 \\
\hline
\end{tabular}

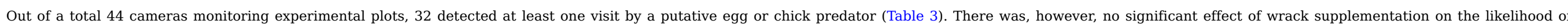
predator presence (binomial GLM, $\beta=0.016 \pm 0.012$ (se), $p=0.207$ ).

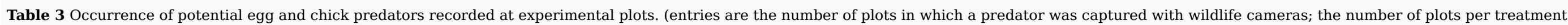
was four).

alt-text: Table 3

\begin{tabular}{|c|c|c|c|c|}
\hline Wrack supplementation & $\begin{array}{l}\text { Magpie (Species names should be on the top line and the units on a separate line below. } \\
\qquad \text { Magpie } \\
\text { No. Plots (n))No. Plots (n) }\end{array}$ & Raven No. Plots (n) & Silver gull No. Plots (n) & Red Fox No. Plots (n) \\
\hline $0 \%$ & 2 & 1 & 0 & 0 \\
\hline $10 \%$ & 2 & 0 & 0 & 0 \\
\hline $20 \%$ & 2 & 0 & 0 & 0 \\
\hline $30 \%$ & 2 & 1 & 0 & 0 \\
\hline $40 \%$ & 2 & 0 & 0 & 1 \\
\hline
\end{tabular}




\begin{tabular}{|l|l|}
\hline $50 \%$ & 2 \\
\hline $60 \%$ & 1 \\
\hline $70 \%$ & 4 \\
\hline $80 \%$ & 3 \\
\hline $90 \%$ & 3 \\
\hline $100 \%$ & 2 \\
\hline
\end{tabular}



\begin{tabular}{|l|l}
\hline & 1 \\
\hline & 0 \\
\hline & 0 \\
\hline & 0 \\
\hline
\end{tabular}

\section{Discussion}

\subsection{Wrack and beach birds}

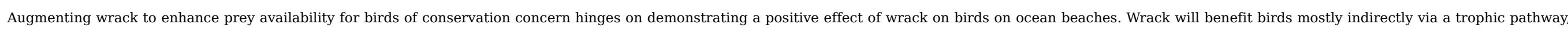

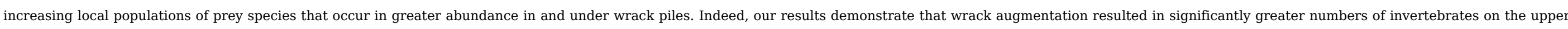
beach near supplemented wrack.

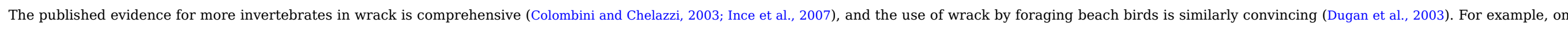

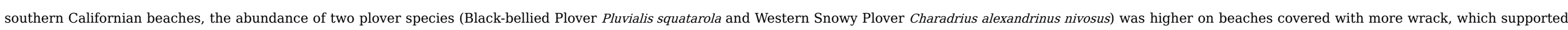

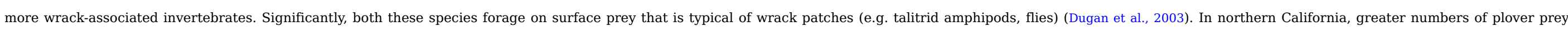


brown algae (Brindock and Colwell, 2011).

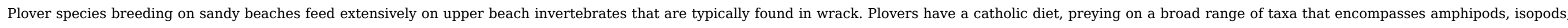

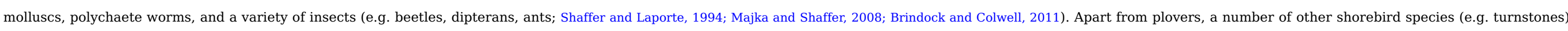

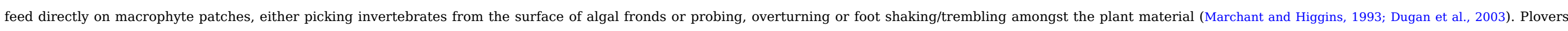



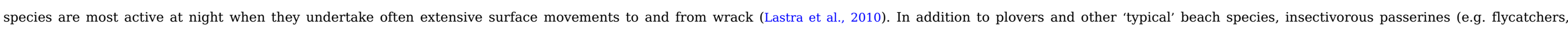
swallows, sparrows, fairy-wrens, starlings) forage regularly along the strandline of beaches where wrack accumulates (Dugan et al., 2003; Meager et al., 2012).



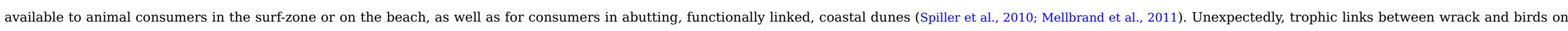

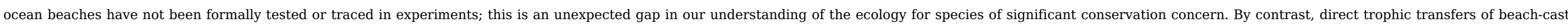
animal carrion to scavenging birds have been comprehensively documented recently (Huijbers et al., 2013, 2015; Brown et al., 2015; Huijbers et al., 2015; Schlacher et al., 2015a; Huijbers et al., 2016).

\subsection{Mechanism(s) of wrack effects}

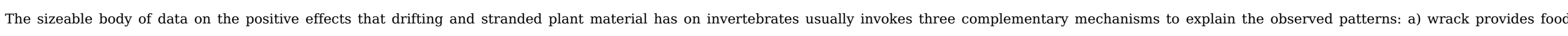

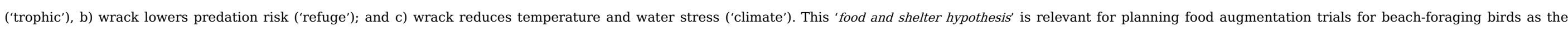
purposeful provisioning with prey needs to understand the processes driving planned increases in prey populations.

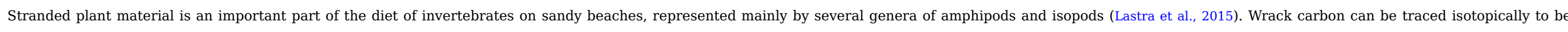

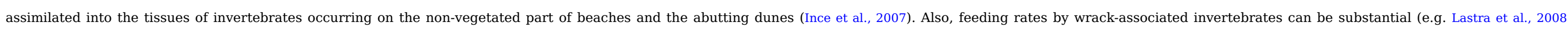

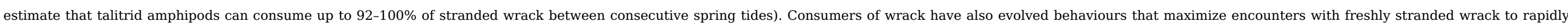






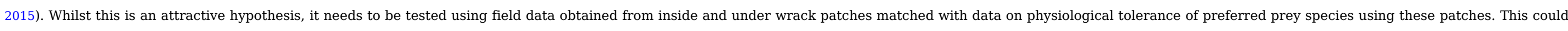
have a bearing on the height and type of wrack experimentally added to create an optimal humidity and temperature environment for the infauna.

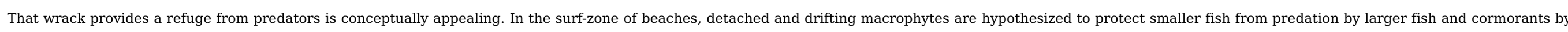

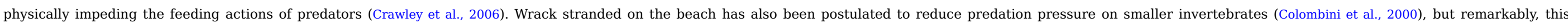



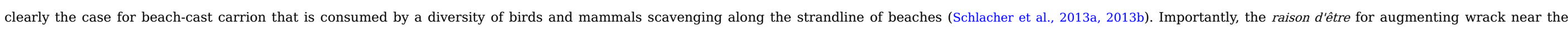

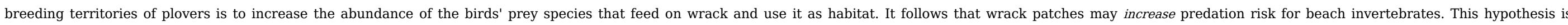
supported by frequent observations of plovers foraging for wrack-invertebrates around the edges of wrack piles (M. Weston pers. obs.)

\subsection{Sharpening the wrack augmentation tool}

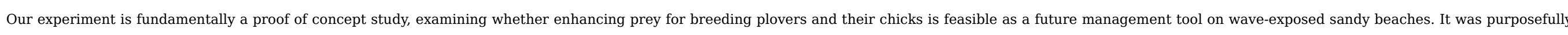

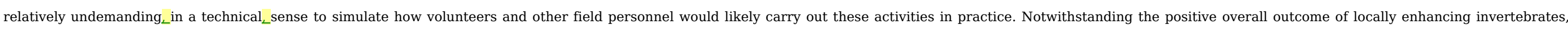

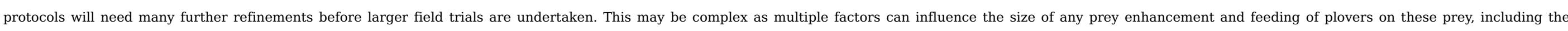
geometry of patches (e.g. size, edge-to-area ratio, height), material properties (e.g. species, age), and spatial configuration (e.g. number of patches, elevation, distance from nest).

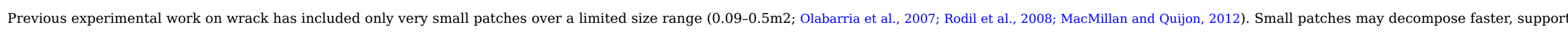

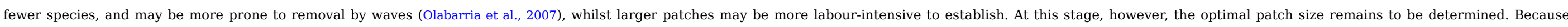

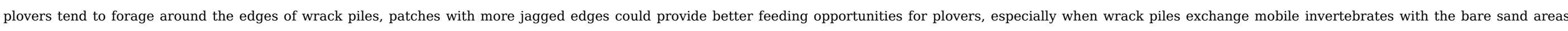

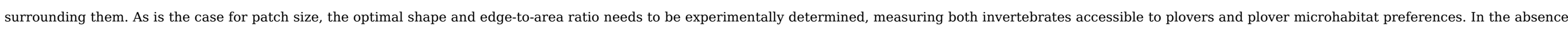
of experimental data, a sensible approach is to mimic the size and shape spectrum of wrack patches naturally occurring on the beach.

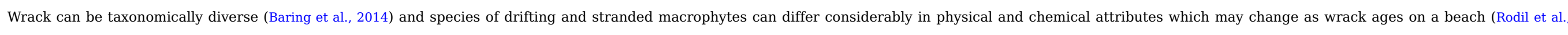

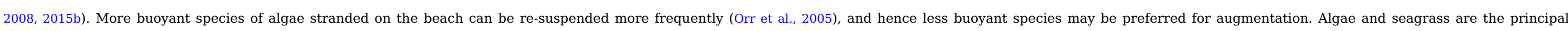

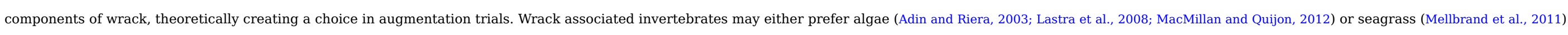

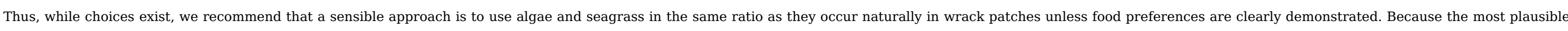

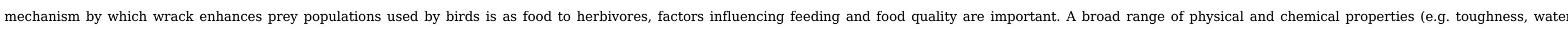

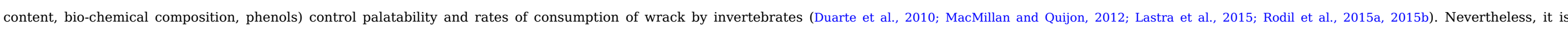
theoretically feasible to improve the performance of wrack augmentation by identifying wrack attributes that yield the highest rates of invertebrate consumption and production.

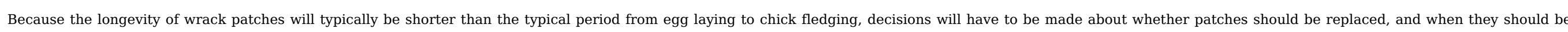

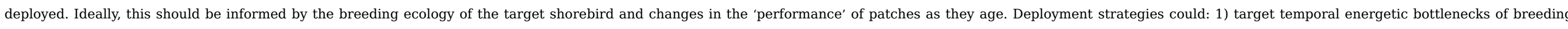

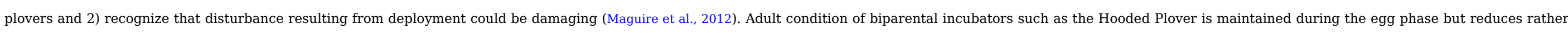



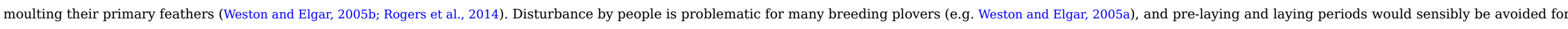

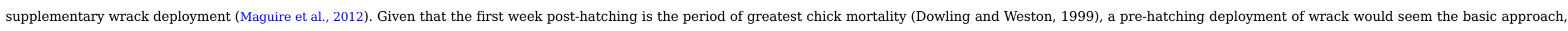
with possible replacement supplementation later in the brood-rearing phase. 






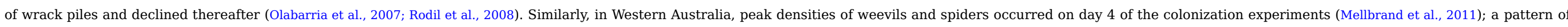

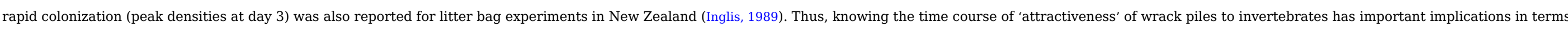

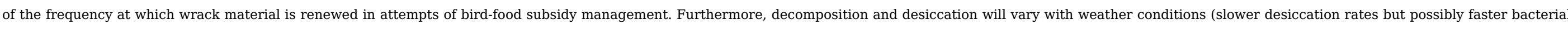


complex, being dependent on age of individuals, water content of algae and the humidity under which they decay, and the species composition of algae in the wrack.

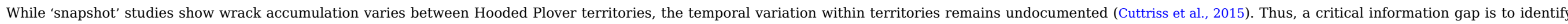

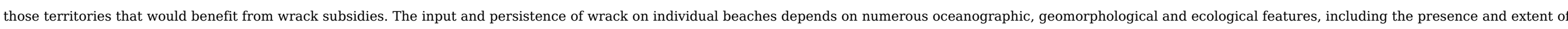

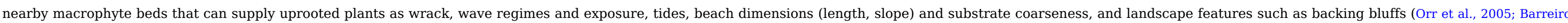

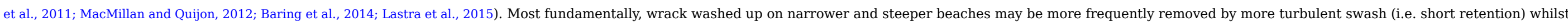




and not benefit from supplementation as much as other beaches.

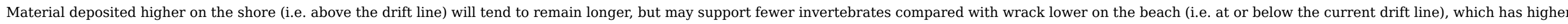

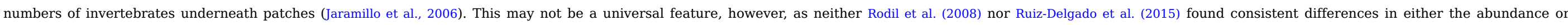

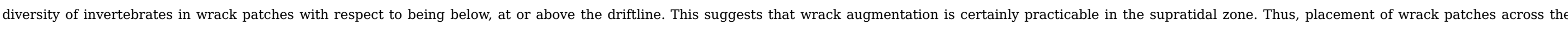

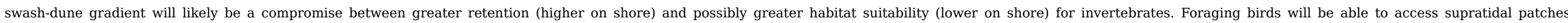
irrespective of tidal phase, whereas more seaward patches are inaccessible during high tides.

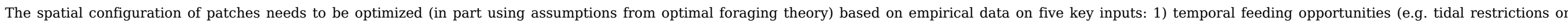

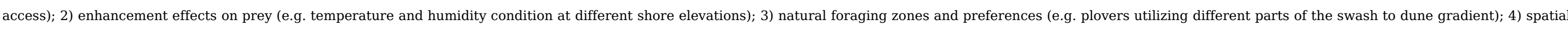

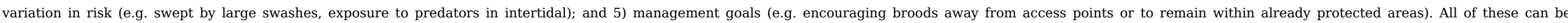

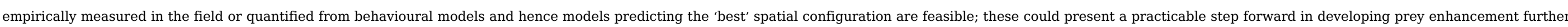
as a tool in beach-bird conservation.

\subsection{Positive and negative side effects?}

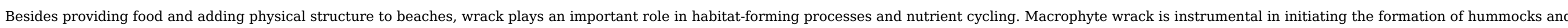

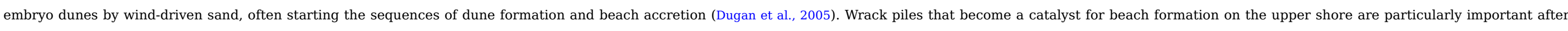

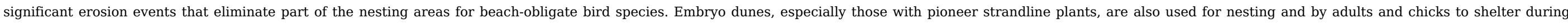


to invertebrate prey species on the beach-face (Soares et al., 1997; Barreiro et al., 2013).

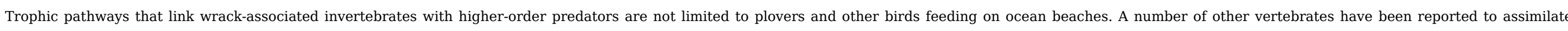



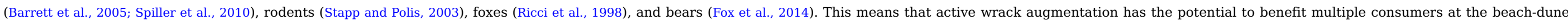








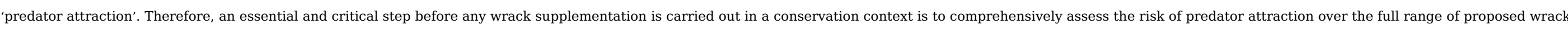

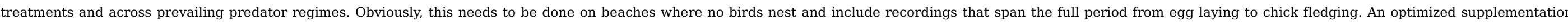

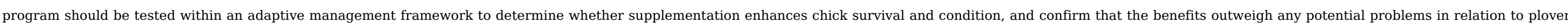
population demographics.

\section{Conclusions}

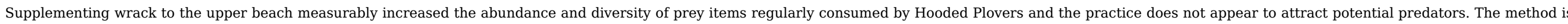

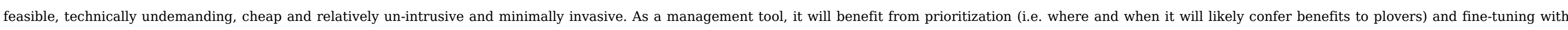

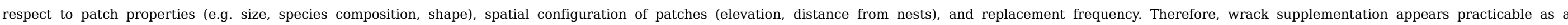
complementary action to improve breeding success in threatened birds that require active management.

\section{Acknowledgements}

We would like to warmly thank Dr Mary Gibson, the Edney family, Lucy Carracher, Alex Kwakernaak, Jonathon Stevenson and Tamara Vekich.

\section{References}

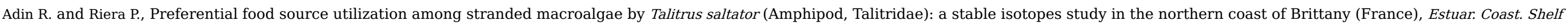
Sci. 56, 2003, 91-98.

Baring R.J., Fairweather P.G. and Lester R.E., Storm versus calm: variation in fauna associated with drifting macrophytes in sandy beach surf zones, J. Exp. Mar. Biol. Ecol. 461, 2014, 397-406.

Barreiro F., Gómez M., Lastra M., López J. and De la Huz R., Annual cycle of wrack supply to sandy beaches: effect of the physical environment, Mar. Ecol. Prog. Ser. 433, 2011, 65-74.

Barreiro F., Gómez M., López J., Lastra M. and de la Huz R., Coupling between macroalgal inputs and nutrients outcrop in exposed sandy beaches, Hydrobiologia 700, 2013, 73-84.

Barrett K., Anderson W.B., Wait D.A., Grismer L.L., Polis G.A. and Rose M.D., Marine subsidies alter the diet and abundance of insular and coastal lizard populations, Oikos 109, 2005, 145-153.

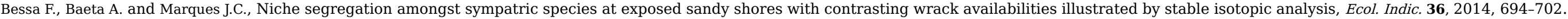

Brindock K.M. and Colwell M.A., Habitat selection by western snowy plovers during the nonbreeding season, J. Wildl. Manag. 75, 2011, 786-793.



Ecology 96, 2015, 2715-2725.

Burnham K.P. and Anderson D.R., Model Selection and Multi-model Inference, 2002, Springer; New York.

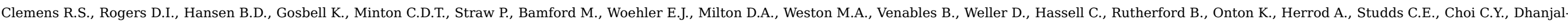

Adams K.L., Murray N.J., Skilleter G.A. and Fuller R.A., Continental-scale decreases in shorebird populations in Australia, Emu 116, 2016, 119-135.

Colombini I., Aloia A., Fallaci M., Pezzoli G. and Chelazzi L., Temporal and spatial use of stranded wrack by the macrofauna of a tropical sandy beach, Mar. Biol. 136, 2000, 531-541.

Colombini I. and Chelazzi L., Influence of marine allochthonous input on sandy beach communities. Oceanography and Marine Biology, An Annu. Rev. 41, 2003, 115-159.

Colwell M.A., Hurley S.J., Hall J.N. and Dinsmore S.J., Age-related survival and behavior of Snowy Plover chicks, Condor 109, 2007, 638-647.

Coupland G.T., Duarte C.M. and Walker D.I., High metabolic rates in beach cast communities, Ecosystems 10, 2007, 1341-1350.

Coupland G.T. and McDonald J.I., Extraordinarily high earthworm abundance in deposits of marine macrodetritus along two semi-arid beaches, Mar. Ecol. Prog. Ser. 361, 2008, 181-189.

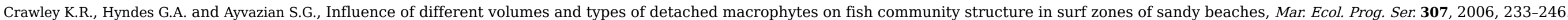


Cuttriss A., Maguire G.S., Ehmke G. and Weston M.A., Breeding habitat selection in an obligate beach bird: a test of the food resource hypothesis, Mar. Freshw. Res. 66, 2015, 841-846.

Duarte C., Navarro J.M., Acuña K. and Gómez I., Feeding preferences of the sandhopper Orchestoidea tuberculata: the importance of algal traits, Hydrobiologia 651, 2010 , $291-303$.

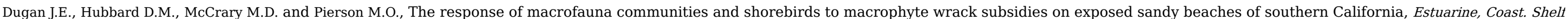
Sci. 58, 2003, 25-40.


the Conference.

Dugan J.E., Hubbard D.M., Page H.M. and Schimel J.P., Marine macrophyte wrack inputs and dissolved nutrients in beach sands, Estuaries Coasts 34, 2011 , 839-850.

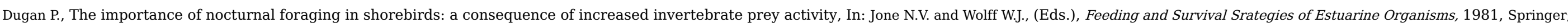
NY, 251-260.

Fox C.H., El-Sabaawi R., Paquet P.C. and Reimchen T.E., Pacific herring Clupea pallasii and wrack macrophytes subsidize semi-Terrestrial detritivores, Mar. Ecol. Prog. Ser. 495, 2014, 49-64.

Guisan A., Edwards T.C., Jr. and Hastie T., Generalized linear and generalized additive models in studies of species distributions: setting the scene, Ecol. Model. 157, 2002, 89-100.

Hastie T.J. and Tibshirani R.J., Generalized Additive Models, 1990, CRC Press.

Heerhartz S.M., Shoreline Armoring Disrupts Marine-terrestrial Connectivity across the Nearshore Ecotone, Doctoral dissertation2013, University of Washington; Seattle.

Heerhartz S.M., Toft J.D., Cordell J.R., Dethier M.N. and Ogston A.S., Shoreline armoring in an estuary constrains wrack-associated invertebrate communities, Estuaries Coasts 39, 2016, 171-188.

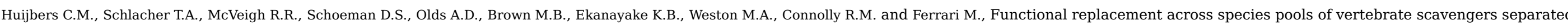
at a continental scale maintains an ecosystem function, Funct. Ecol. 30, 2016, 998-1005.

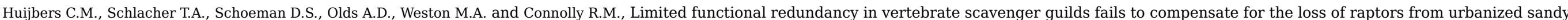

beaches, Divers. Distributions 21, 2015, 55-63.

Huijbers C.M., Schlacher T.A., Schoeman D.S., Weston M.A. and Connolly R.M., Urbanisation alters processing of marine carrion on sandy beaches, Landsc. Urban Plan. 119, 2013, 1-8.

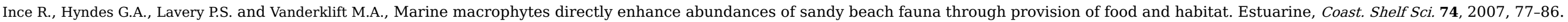

Inglis G., The colonisation and degradation of stranded Macrocystis pyrifera (L.) C. Ag. by the macrofauna of a New Zealand sandy beach, J. Exp. Mar. Biol. Ecol. 125, 1989 , 203-217.

Jaramillo E., De La Huz R., Duarte C. and Contreras H., Algal wrack deposits and macroinfaunal arthropods on sandy beaches of the Chilean coast, Rev. Chil. Hist. Nat. 79, 2006, 337-351.

Jennings S.B., Brown N.D. and Sheil D., Assessing forest canopies and understorey illumination: canopy closure, canopy cover and other measures, Forestry 72, $1999,59-74$.

Lastra M., López J. and Neves G., Algal decay, temperature and body size influencing trophic behaviour of wrack consumers in sandy beaches, Mar. Biol. 162, 2015, 221-233.

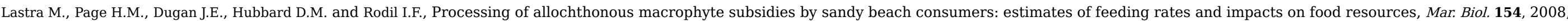
$163-174$.

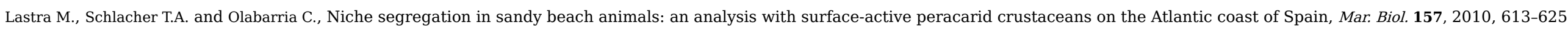

MacMillan M.R. and Quijon P.A., Wrack patches and their influence on upper-shore macrofaunal abundance in an Atlantic Canada sandy beach system, J. Sea Res. 72, 2012 , 28-37.

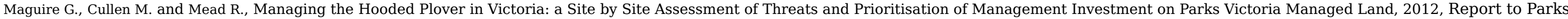

Victoria, 315 pp.. 


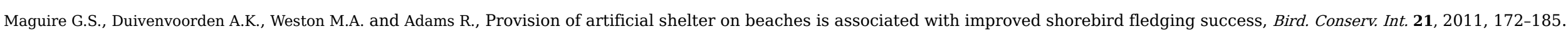

Majka C.G. and Shaffer F., Beetles (Coleoptera) in the diet of Piping Plovers in the Iles de la Madeleine, Québec, Canada, Wader Study Group Bull. 115, 2008 , 77-83.

Marchant S. and Higgins P.J., Handbook of australian, New Zealand and Antarctic Birds vol. 2, 1993, Oxford University Press; Melbourne.

Maslo B. and Lockwood J.L., Evidence-based decisions on the use of predator exclosures in shorebird conservation, Biol. Conserv. 142, 2009, 3213-3218.

McArdle B.H. and Anderson M.J., Fitting multivariate models to community data: a comment on distance-based redundancy analysis, Ecology 82, $2001,290-297$.

Meager J.J., Schlacher T.A. and Nielsen T., Humans alter habitat selection of birds on ocean-exposed sandy beaches, Divers. Distributions 18, 2012, 294-306.

Mellbrand K., Lavery P.S., Hyndes G. and Hambäck P.A., Linking land and sea: different pathways for marine subsidies, Ecosystems 14, $2011,732-744$.

Morrow K., Bell S.S. and Tewfik A., Variation in ghost crab trophic links on sandy beaches, Mar. Ecol. Prog. Ser. 502, 2014, 197-206.

Olabarria C., Lastra M. and Garrido J., Succession of macrofauna on macroalgal wrack of an exposed sandy beach: effects of patch size and site, Mar. Environ. Res. 63, 2007, 19-40.

Orr M., Zimmer M., Jelinski D.E. and Mews M., Wrack deposition on different beach types: spatial and temporal variation in the pattern of subsidy, Ecology 86, $2005,1496-1507$.

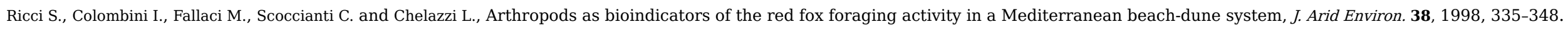



Rodil I.F., Olabarria C., Lastra M. and Arenas F., Combined effects of wrack identity and solar radiation on associated beach macrofaunal assemblages, Mar. Ecol. Prog. Ser. 531, 2015b, 167-178.

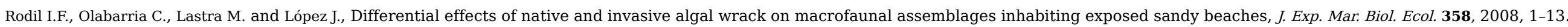

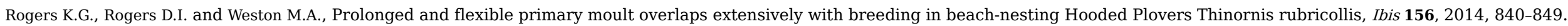

Romanuk T.N. and Levings C.D., Reciprocal subsidies and food web pathways leading to chum salmon fry in a temperate marine-terrestrial ecotone, PLoS One 5, 2010.

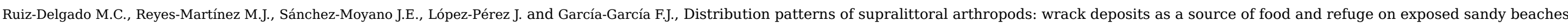

(SW Spain), Hydrobiologia 742, 2015, 205-219.

Schlacher T.A., Strydom S. and Connolly R.M., Multiple scavengers respond rapidly to pulsed carrion resources at the land-ocean interface, Acta Oecol. 48, 2013 a, 7-12.

Schlacher T.A., Strydom S., Connolly R.M. and Schoeman D., Donor-control of scavenging food webs at the land-ocean interface, PLoS One 8, $2013 \mathrm{~b}$, e68221.

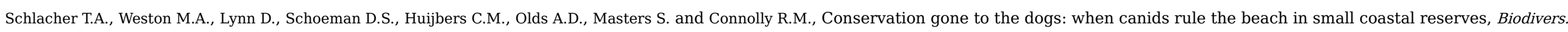

Conservation 24, 2015a, 493-509.

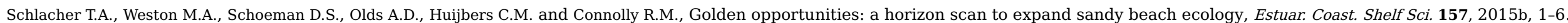

Shaffer F. and Laporte P., Diet of Piping Plovers on the Magdalen Islands, 1994, The Wilson Bulletin; Quebec, 531-536.

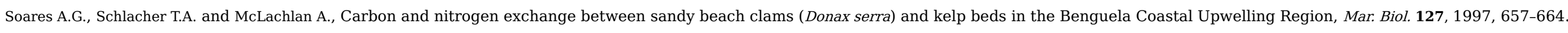

Spiller D.A., Piovia-Scott J., Wright A.N., Yang L.H., Takimoto G., Schoener T.W. and Iwata T., Marine subsidies have multiple effects on coastal food webs, Ecology 91, 2010, 1424-1434.

Staine K.J. and Burger J., Nocturnal foraging behavior of breeding Piping Plovers (Charadrius melodus) in New Jersey, Auk 1994, 579-587.

Stapp P. and Polis G.A., Marine resources subsidize insular rodent populations in the Gulf of California, Mexico, Oecologia 134, 2003, $496-504$.

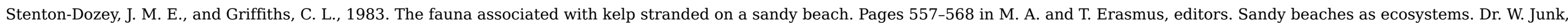


The Hague.

Tewfik A., Bell S.S., McCann K.S. and Morrow K., Predator diet and trophic position modified with altered habitat morphology, PLoS One 11, 2016

Weston M.A. and Elgar M.A., Disturbance to brood-rearing Hooded Plover Thinornis rubricollis: responses and consequences, Bird. Conserv. Int. 15, 2005 a, 193-209.

Weston M.A. and Elgar M.A., Parental care in hooded plovers (Thinornis rubricollis), Emu 105, 2005b, 283-292.

Weston M.A., Schlacher T.A. and Lynn D., Pro-environmental beach driving is uncommon and ineffective in reducing disturbance to beach-dwelling birds, Environ. Manag. 53, 2014, 999-1004.

Zuur A.F., Leno E.N., Walker N.J., Saveliev A.A. and Smith G.M., Mixed Effects Models and Extensions in Ecology with R, 2009, Springer; New York.

\section{Queries and Answers}

Query: Please check the affiliation "b" and "c" and correct if necessary.

\section{Answer: SCHLACHER, Thomas A. ${ }^{\text {a }}$}

tschlach@usc.edu.au

\section{HUTTON, Briony M. ${ }^{\text {b }}$}

bhutton@deakin.edu.au

GILBY, Ben L. a

bgilby@usc.edu.au

PORCH, Nicholaus b

nporch@deakin.edu.au

MAGUIRE, Grainne S. c

Grainne.Maguire@birdlife.org.au

MASLO, Brooke

brooke.maslo@rutgers.edu

CONNOLLY, Rod M. e

r.connolly@griffith.edu.au

OLDS, Andrew D. a

aolds@usc.edu.au

\section{WESTON, Michael A. ${ }^{\text {b }}$}

mike.weston@deakin.edu.au

a School of Science and Engineering, The University of the Sunshine Coast, Q-4558 Maroochydore, Australia

b School of Life and Environmental Sciences \& Centre for Integrative Ecology, Deakin University, Burwood \& Geelong, Australia

c BirdLife Australia, Suite 2-05, The Green Building, 60 Leicester Street, Carlton, Victoria, 3053, Australia;

d Department of Ecology, Evolution and Natural Resources. Rutgers, The State University of New Jersey, USA

e Australian Rivers Institute - Coast \& Estuaries \& School of Environment, Gold Coast Campus, Griffith University, Australia

Query: The country name has been inserted for the affiliation "e". Please check, and correct if necessary. 


\section{Answer: correct}

Query: Please check the edits made in the affiliation " $\mathrm{f}$ " and correct if necessary.

Answer: correct

Query: Could you please provide the grant number for Western, if any?

Answer: none available

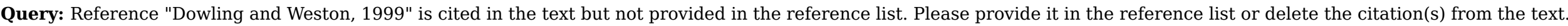

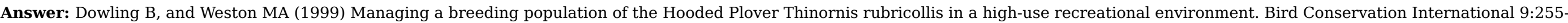
270.

Query: Reference Lastra et al., 2010a and 2010b are same.Hence, to avoid the repeatation, we have retained once as Lastra et al., 2010. Please check and correct if necessary. Answer: correct

Query: Please check that the affiliations link the authors with their correct departments, institutions, and locations, and correct if necessary.

\section{Answer: SCHLACHER, Thomas A. ${ }^{\text {a }}$}

tschlach@usc.edu.au

HUTTON, Briony M. b

bhutton@deakin.edu.au

GILBY, Ben L. a

bgilby@usc.edu.au

PORCH, Nicholaus b

nporch@deakin.edu.au

MAGUIRE, Grainne S.

Grainne.Maguire@birdlife.org.au

MASLO, Brooke

brooke.maslo@rutgers.edu

CONNOLLY, Rod M. e

r.connolly@griffith.edu.au

OLDS, Andrew D. a

aolds@usc.edu.au

WESTON, Michael A. b

mike.weston@deakin.edu.au

a School of Science and Engineering, The University of the Sunshine Coast, Q-4558 Maroochydore, Australia

b School of Life and Environmental Sciences \& Centre for Integrative Ecology, Deakin University, Burwood \& Geelong, Australia

c BirdLife Australia, Suite 2-05, The Green Building, 60 Leicester Street, Carlton, Victoria, 3053, Australia; 
d Department of Ecology, Evolution and Natural Resources. Rutgers, The State University of New Jersey, USA

e Australian Rivers Institute - Coast \& Estuaries \& School of Environment, Gold Coast Campus, Griffith University, Australia

Query: Please confirm that given names and surnames have been identified correctly.

Answer: Yes

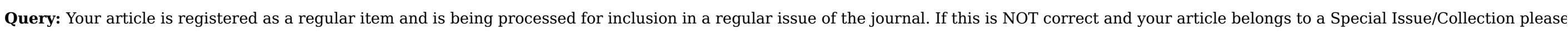
contact go.mohan@elsevier.com immediately prior to returning your corrections.

Answer: Yes 